\title{
PEMODELAN SPASIAL DATA PANEL UNTUK MENENTUKAN FAKTOR-FAKTOR YANG MEMPENGARUHI KESEHATAN DI PROVINSI PAPUA
}

\author{
Ira Rosianal Hikmah'), Yulial Hikmah ${ }^{2)}$ \\ ${ }^{1}$ Sekolah Tinggi Sandi Negara \\ Email: ira.rosianal@stsn-nci.ac.id \\ ${ }^{2}$ Program Pendidikan Vokasi Universitas Indonesia \\ Email: yulialhikmah47@ui.ac.id
}

\begin{abstract}
According to data from the BPS, the rate of population growth in Indonesia consistently increases every year. Conditions of population growth that cannot be suppressed will cause several problems. One of the problems in Indonesia and difficult to solve is the public health problem. Until now, the number of sick people in Indonesia is still quite high. The spatial panel model is the result of the development of the panel data model. This development was carried out because of the influence of spatial or location on panel data. Spatial information is very important because it can determine the relationship of an area with other regions that are close together. Data containing spatial elements will not be accurate if only using panel regression analysis because there are assumptions that are violated, one of which will produce heterogeneous errors. This is due to the inter-regional linkages. The purpose of this study was to determine the factors that influence the percentage of sick people in Papua Province based on several selected spatial panel models, namely SAR, SEM, GSM models. Next, an analysis was conducted to obtain the best spatial panel model.
\end{abstract}

Keywords: Public health, spatial panel model, SAR, SEM, GSM

\begin{abstract}
ABSTRAK
Menurut data BPS, tingkat pertumbuhan populasi di Indonesia secara konsisten meningkat setiap tahun. Kondisi pertumbuhan populasi yang tidak dapat ditekan akan menyebabkan berbagai masalah. Salah satu masalah yang mungkin terjadi di Indonesia dan sulit diselesaikan adalah kesehatan masyarakat Indonesia. Hingga saat ini, jumlah penduduk sakit di Indonesia masih cukup tinggi. Model panel spasial merupakan hasil pengembangkan model data panel. Pengembangan ini dilakukan karena adanya pengaruh spasial atau lokasi pada data panel. Informasi spasial sangat penting karena dapat menentukan hubungan suatu daerah dengan daerah lain yang berdekatan. Data yang mengandung elemen spasial tidak akan akurat jika hanya menggunakan regresi panel karena ada asumsi yang dilanggar, salah satunya akan menghasilkan kesalahan yang heterogen. Hal ini disebabkan karena adanya hubungan antar wilayah. Tujuan dari penelitian ini adalah menentukan faktor-faktor yang mempengaruhi persentase penduduk sakit di Provinsi Papua berdasarkan beberapa model panel spasial yang dipilih, yaitu model SAR, SEM, dan GSM. Selanjutnya dilakukan analisis untuk mendapatkan model panel spasial terbaik.
\end{abstract}

Kata kunci: Kesehatan masyarakat, model panel spasial, SAR, SEM, GSM 


\section{PENDAhULUAN}

Menurut data dari Badan Pusat Statistik (BPS) tahun 2010 dari hasil sensus penduduk menyatakan bahwa laju pertumbuhan penduduk di Indonesia meningkat sebesar 1,49\% pertahunnya (Rahayu, 2010). Kondisi pertumbuhan penduduk yang tidak dapat ditekan akan menimbulkan beberapa permasalahan. Salah satu permasalahan di Indonesia dan sulit untuk diselesaikan adalah masalah kesehatan masyarakat. Hal ini dikarenakan sebagian masyarakat Indonesia belum mendapatkan pelayanan kesehatan karena biaya kesehatan yang terus menerus meningkat. Permasalahan kesehatan menjadi salah satu fokus pemerintah selain masalah kemiskinan dan pendidikan. Sejumlah program dan kebijakan-kebijakan telah dilaksanakan untuk meningkatkan tingkat kesehatan masyarakat. Namun sampai saat ini, jumlah penduduk sakit di Indonesia masih cukup tinggi.

Sejak tahun 2014, Indonesia telah mengangkat Program Indonesia Sehat sebagai upaya mempromosikan pelayanan kesehatan yang bermutu dan mendorong semua orang untuk mencapai tingkat kesehatan tertinggi. Program Indonesia Sehat terdiri dari tiga elemen yaitu Paradigma Sehat, Penguatan Pelayanan Kesehatan Primer, dan JKN. Paradigma Sehat dilakukan dengan promosi kesehatan dengan pemberdayakan masyarakat melalui Gerakan Masyarakat Hidup Sehat (GERMAS). Penguatan Pelayanan Kesehatan Primer dilakukan untuk meningkatkan layanan kuratif dan rehabilitasi melalui pendekatan berbasis keluarga dalam rangka pencapaian standar pelayanan minimum kesehatan. JKN yaitu Jaminan Kesehatan Nasional untuk memastikan akses masyarakat terhadap layanan kesehatan yang terjangkau (Kementerian Kesehatan Republik Indonesia, 2019).

Riset Kesehatan Dasar (Riskesdas) merupakan riset skala nasional yang dilakukan oleh Badan Litbangkes Kementerian Kesehatan RI untuk mendapatkan gambaran mengenai bagaimana kesehatan masyarakat Indonesia baik di tingkat nasional, provinsi, maupun kabupaten/kota. Riskesdas pertama kali dilakukan pada tahun 2007, kemudian dilakukan lagi tahun 2010, 2013, dan yang terbaru adalah tahun 2018. Data riskesdas meliputi kondisi kesehatan masyarakat dari berbagai usia, jenis kelamin, penyakit, serta gaya hidup (Kumparan, 2019). Riset Kesehatan Dasar (Riskesdas) 2018 mencatat bahwa Kementerian Kesehatan Republik Indonesia hanya mampu mengurangi angka stunting (pendek/kerdil) dari 37,2\% menjadi 30,8\% selama lima tahun. Begitu pula dengan gizi buruk, dari 19,6\% menjadi 17,6\%. Pada awal tahun 2018, kabar gizi buruk dan campak datang dari Asmat, Papua. Tercatat 76 anak meninggal dunia akibat gizi buruk dan campak. Pemerintah Indonesia bahkan langsung mengkategorikan kasus ini ke dalam Kejadian Luar Biasa (KLB) dan membentuk tim khusus yang turun langsung ke Asmat. Akses kesehatan berupa fasilitas kesehatan, tenaga medis, dan obat-obatan yang jauh dari masyarakat Asmat serta pendidikan yang rendah menjadi penyebab gizi buruk dan campak mewabah di Asmat. Di sisi lain, angka obesitas justru mengalami peningkatan dari 14,8\% menjadi 21,8\% (CNN Indonesia, 2018).

Hampir semua penyakit tidak menular seperti kanker, stroke, gangguan ginjal kronis, diabetes, dan hipertensi, mengalami peningkatan. Akan tetapi, jumlah penderita penyakit menular seperti infeksi saluran pernapasan, malaria, diare, dan tuberkulosis mengalami penurunan. Walaupun demikian, Indonesia masih dihadapi tantangan karena banyak masyarakat yang menolak pemberian vaksin untuk mencegah penyakit menular. Polemik kehalalan vaksin MR dan polio menjadi salah satu penyebabnya. Majelis Ulama Indonesia sudah mengeluarkan fatwa bahwa vaksin boleh digunakan hingga terdapat pengganti yang halal (CNN Indonesia, 2018). Hasil utama Riskesdas 2018 menyebutkan bahwa provinsi dengan prevalensi ispa dan pneumonia tertinggi di Indonesia adalah Papua. Sedangkan prevalensi TB paru, provinsi Papua tertinggi kedua setelah Banten. Selain itu, provinsi papua 
menjadi daerah prevalensi diare pada balita tertinggi di Indonesia. Oleh karena itu, penelitian ini akan memfokuskan pada permasalahan kesehatan di Provinsi Papua (Kementerian Kesehatan Republik Indonesia, 2018).

Terdapat banyak sekali faktor yang mempengaruhi permasalahan kesehatan di Provinsi Papua, di antaranya adalah faktor lingkungan dan gaya hidup (Kementerian Kesehatan Republik Indonesia, 2018). Menurut data BPS, pada tahun 2018, Papua menjadi provinsi dengan persentase rumah tangga kumuh perkotaan tertinggi di Indonesia yaitu sebesar $17 \%$. Papua juga tercatat sebagai provinsi dengan persentase rumah tangga yang memiliki akses terhadap layanan sanitasi layak dan berkelanjutan terendah sebesar $15,78 \%$. Selain sanitasi, Provinsi Papua juga menempati peringkat kelima setelah Bengkulu, Lampung, Kalimantan Selatan, dan Sulawesi Barat dengan persentase terendah yang memiliki akses terhadap layanan sumber air minum layak dan berkelanjutan (Badan Pusat Statistik, 2019). Angka kematian balita per 1000 kelahiran hidup tertinggi di Indonesia juga ditempati oleh Papua (Badan Pusat Statistik, 2018). Salah satu penyebabnya adalah rendahnya persentase balita yang pernah mendapatkan imunisasi sehingga mudah terkena penyakit. Selain itu, rendahnya pendidikan akan gaya hidup sehat di Provinsi Papua juga cukup rendah. Salah satunya terlihat dari hasil utama Riskesdas 2018 dengan proporsi perilaku cuci tangan dengan benar pada usia lebih dari 10 tahun, terendah kedua setelah NTT (Kementerian Kesehatan Republik Indonesia, 2018). Oleh karena itu, penelitian ini juga memfokuskan pada faktor-faktor yang mungkin menjadi penyebab dan mempengaruhi permasalahan kesehatan di Indonesia, yaitu persentase keluhan kesehatan, rata-rata lama sakit, ketersediaan fasilitas $\mathrm{BAB}$, ketersediaan sumber air minum, dan persentase imunisasi balita.

Data yang terdiri dari beberapa objek yang diamati pada satu waktu disebut dengan data lintas individu (cross section). Sedangkan data yang dikumpulkan dari beberapa waktu untuk satu objek saja disebut dengan data deret waktu (time series). Penggunaan data terkadang tidak cukup dengan menggunakan informasi yang diberikan oleh data cross section atau data time series saja. Penggabungan keduanya mampu mengendalikan keragaman individu. Selain itu juga mampu memberikan data yang lebih informatif, antar variabel memiliki hubungan (multikolinieritas) yang rendah serta lebih efisien. Penggabungan data cross section dan data time series ini disebut dengan data panel (Baltagi, 2005).

Pada penelitian ini, objek data yang diperoleh dari BPS adalah lokasi. Seringkali model regresi data panel diterapkan pada beberapa wilayah sehingga galat/error yang dihasilkan menjadi heterogen akibat keterkaitan antar wilayah (otokorelasi spasial). Kondisi seperti ini mengakibatkan perlu dilakukan pertimbangan terhadap analisis kebergantungan spasial. Regresi spasial merupakan hasil pengembangan dari model linier klasik. Pengembangan ini berdasarkan pada adanya pengaruh tempat atau spasial pada data yang dianalisis (Anselin, 2009). Informasi mengenai posisi sangatlah penting karena memungkinkan untuk mengetahui hubungan suatu elemen di suatu daerah dengan daerah lain yang saling berdekatan. Dengan melihat kondisi diatas dapat disimpulkan bahwa selain data panel, data kesehatan penduduk memiliki unsur spasial di dalamnya. Dalam menganalisis data yang mengandung unsur spasial, maka analisis data tidak akan akurat jika hanya menggunakan analisis regresi sederhana. Jika menggunakan analisis regresi sederhana maka akan terjadi kesalahan asumsi seperti nilai residual yang berkorelasi dengan yang lain serta ragamnya tidak konstan (Pangestika, 2015). Sementara jika hanya menggunakan regresi panel saja tanpa memasukkan unsur spasial akan menghasilkan galat/error yang heterogen yang diakibatkan keterkaitan antar wilayah (otokorelasi spasial) (Elhorst, 2010). 
Oleh karena itu, dibutuhkan metode pengolahan data yang dapat mengakomodasi hal tersebut, dalam hal ini adalah regresi panel spasial. Sebelumnya Halim (2008) telah menggunakan regresi spasial untuk memodelkan harga jual apartemen di Surabaya. Selain itu Anggraeni (2012) menggunakan analisis panel spasial untuk menganalisis faktor yang mempengaruhi kemiskinan di provinsi Sumatera Selatan. Meilliana (2013) menggunakan regresi panel untuk menganalisis faktor-faktor yang mempengaruhi IPM di provinsi Jawa Timur. Pada penelitian ini, analisis panel spasial diterapkan untuk mengetahui faktor-faktor yang mempengaruhi persentase penduduk sakit di Provinsi Papua.

\section{METODOLOGI}

\subsection{Data}

Data yang digunakan dalam penelitian ini merupakan data sekunder yang diperoleh dari Badan Pusat Statistik (BPS). Data panel yang digunakan adalah data di dua puluh sembilan kabupaten/ kota yang ada di Provinsi Papua dengan periode waktu dari tahun 2013 sampai tahun 2017 dengan keterangan variabel sebagai berikut:

Tabel 1 Variabel dalam Penelitian

\begin{tabular}{ll}
\hline Nama Variabel & Satuan \\
\hline Persentase penduduk sakit (Y) & Persen \\
Persentase keluhan kesehatan (X1) & Persen \\
Rata-rata lama sakit (X2) & Hari \\
Fasilitas BAB sendiri (X3) & Persen \\
Fasilitas BAB bersama (X4) & Persen \\
Persentase balita tidak imunisasi BCG (X5) & Persen \\
Persentase balita tidak imunisasi DPT (X6) & Persen \\
Persentase balita tidak imunisasi POLIO (X7) & Persen \\
Persentase balita tidak imunisasi CAMPAK (X8) & Persen \\
Persentase balita tidak imunisasi HEPATITIS B (X9) & Persen \\
Sumber air minum sumur terlindungi (X10) & Persen \\
\hline
\end{tabular}

\subsection{Metode Analisis} berikut:

Tahapan yang akan dilakukan dalam analisis data panel spasial adalah sebagai

1. Menghitung korelasi variabel bebas $(\mathrm{X})$ terhadap variabel terikat $(\mathrm{Y})$.

2. Melakukan analisis data panel.

3. Melakukan analisis spasial.

4. Melakukan analisis data panel spasial.

5. Pemilihan model terbaik dengan melihat nilai $\mathrm{R}^{2}$ terbesar.

\section{HASIL DAN PEMBAHASAN}

\subsection{Korelasi Variabel Penjelas}

Tabel 2 menunjukkan korelasi antar variabel bebas dengan variabel terikatnya di setiap tahunnya. Berdasarkan Tabel 2 terlihat bahwa persentase keluhan sakit berkorelasi positif terhadap persentase pendiduk sakit. 


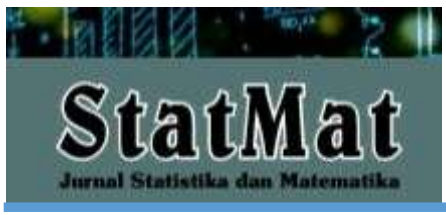

Tabel 2 Koefisien korelasi variabel $Y$ dengan $X$

\begin{tabular}{ccccccccccc}
\hline & & & & & Y- & Y- & Y- & Y- & Y- & Y- \\
& Y-X1 & Y-X2 & Y-X3 & Y-X4 & X5 & X6 & X7 & X8 & X9 & X10 \\
\hline 2013 & 0.873 & 0.028 & -0.241 & 0.211 & 0.261 & 0.275 & 0.302 & 0.232 & 0.209 & -0.009 \\
2014 & 0.869 & -0.249 & -0.266 & 0.243 & 0.186 & 0.209 & 0.179 & 0.181 & 0.154 & -0.065 \\
2015 & 0.835 & 0.185 & -0.239 & 0.303 & 0.561 & 0.581 & 0.573 & 0.567 & 0.583 & -0.274 \\
2016 & 0.731 & 0.306 & -0.210 & 0.236 & 0.417 & 0.386 & 0.345 & 0.361 & 0.383 & -0.451 \\
2017 & 0.773 & 0.286 & -0.65307 & 0.641 & 0.287 & 0.245 & 0.247 & 0.194 & 0.294 & 0.076 \\
\hline
\end{tabular}

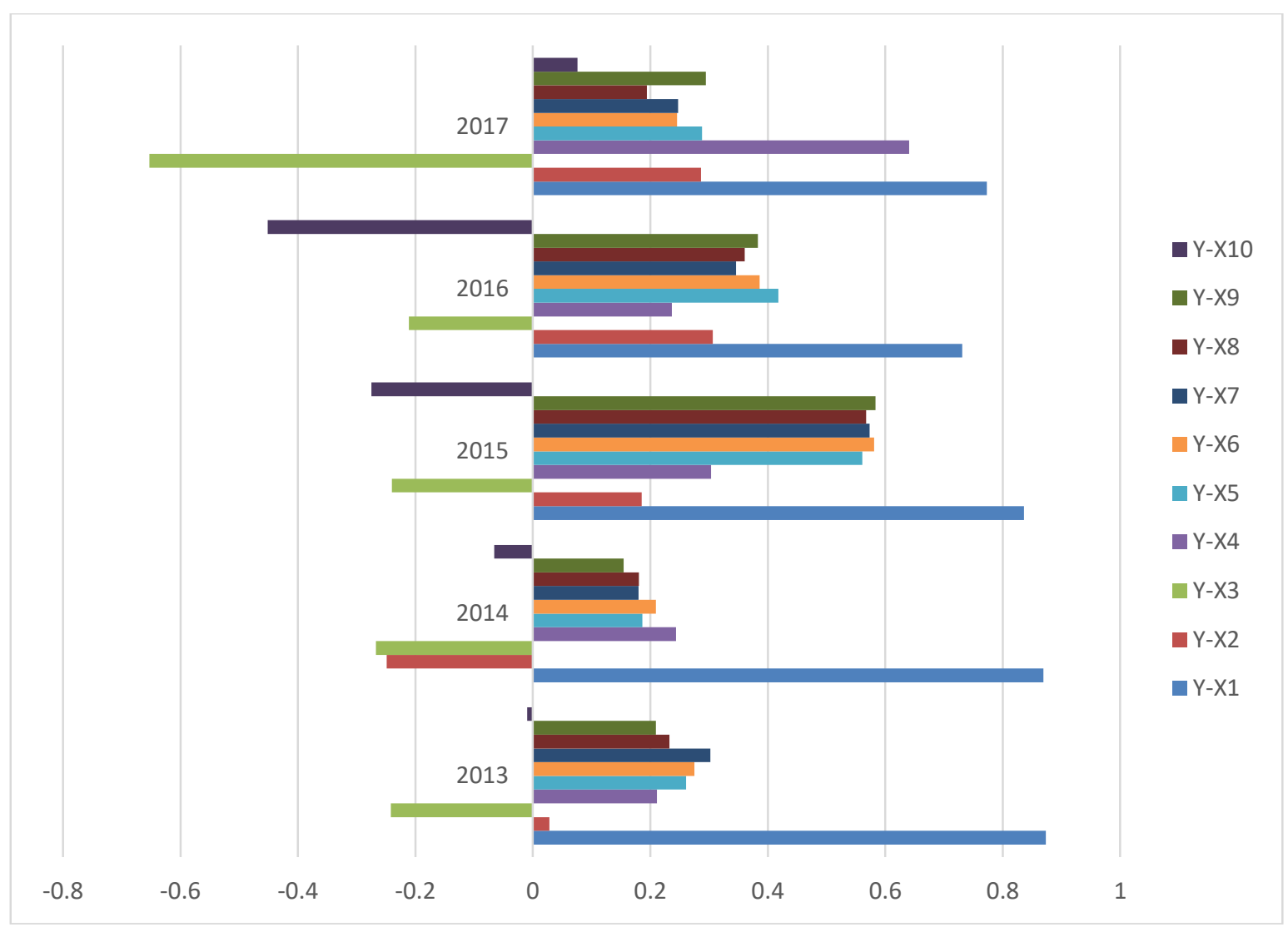

Gambar 1 Koefisien korelasi antar X dengan Y

Pada Gambar 1 terlihat bahwa variabel X3 memberikan korelasi negatif terhadap variabel respon di setiap tahunnya dan X10 juga berkorelasi negatif di hampir setiap tahun sementara variabel lainnya memberikan korelasi yang positif hampir di setiap tahunnya terhadap variabel persentase penduduk sakit. Dari keempat variabel penjelas, yang memberikan pengaruh paling signifikan adalah variabel persentase keluhan sakit.

\subsection{Analisis Data Panel}

Pada analisis data panel spasial, dilakukan terlebih dahulu uji Breusch-Pagan untuk melihat apakah ada efek waktu dan atau individu. Jika digunakan taraf signifikansi sebesar 5\% maka keputusannya dari Tabel 3 adalah terdapat efek individu pada model. Hal ini 
dikarenakan oleh nilai-p $<5 \%$ sehingga tidak ada pengaruh signifikan yang diakibatkan oleh efek waktu.

\section{Tabel 3 Hasil Uji Breusch-Pagan}

\begin{tabular}{lcc}
\multicolumn{1}{c}{ Efek } & $\chi^{\mathbf{2}}$ & Nilai-p \\
\hline Waktu dan Individu & 3,94 & 0,1395 \\
Waktu & 0,0653 & 0,7983 \\
Individu & 3,8746 & 0,049 \\
\hline
\end{tabular}

Selanjutnya, akan diberikan hasil pendugaan model panel pengaruh tetap, acak, dan gabungan.

Tabel 4 Hasil Pendugaan Model Pengaruh Tetap

\begin{tabular}{|c|c|c|}
\hline Variabel & Koefisien & Nilai-p \\
\hline $\mathrm{X} 1$ & 0,625 & $<0,000$ \\
\hline $\mathrm{X} 2$ & 0,358 & 0,03 \\
\hline $\mathrm{X} 3$ & $-0,019$ & 0,04 \\
\hline $\mathrm{X} 4$ & 0,005 & 0,03 \\
\hline X5 & $-0,009$ & 0,82 \\
\hline X6 & 0,082 & 0,04 \\
\hline $\mathrm{X} 7$ & $-0,016$ & 0,73 \\
\hline X8 & $-0,03$ & 0,36 \\
\hline X9 & $-0,041$ & 0,21 \\
\hline $\mathrm{X} 10$ & $-0,001$ & 0,04 \\
\hline \multicolumn{2}{|c|}{$R^{2}$} & 0,7932 \\
\hline
\end{tabular}

Tabel 5 Hasil Pendugaan Model Pengaruh Acak

\begin{tabular}{|c|c|c|}
\hline Variabel & Koefisien & Nilai-p \\
\hline $\mathrm{X} 1$ & 0,534 & $<0,000$ \\
\hline $\mathrm{X} 2$ & 0,417 & 0,04 \\
\hline X3 & 0,006 & 0,64 \\
\hline $\mathrm{X} 4$ & 0,007 & 0,61 \\
\hline X5 & $-0,066$ & 0,14 \\
\hline X6 & 0,074 & 0,09 \\
\hline X7 & 0,041 & 0,4 \\
\hline X8 & $-0,011$ & 0,73 \\
\hline X9 & $-0,064$ & 0,06 \\
\hline $\mathrm{X} 10$ & 0,008 & 0,54 \\
\hline \multicolumn{2}{|c|}{$R^{2}$} & 0,5853 \\
\hline
\end{tabular}

Berdasarkan hasil pendugaan parameter model yang ditampikan pada Tabel 4, Tabel 5 , dan Tabel 6 , terlihat bahwa pada model pengaruh tetap, variabel yang signifikan adalah variabel X1, X2, X3, X4, X6, dan X10. Pada model pengaruh acak, hanya variabel X1 dan $\mathrm{X} 2$ yang signifikan sedangkan untuk model pengaruh gabungan, hanya variabel $\mathrm{X} 1$, X2, dan X3 yang signifikan. Selanjutnya Tabel 7, 8, dan 9 menunjukkan Hasil Pendugaan Model yang hanya melibatkan variabel-variabel yang signifikan. 
Tabel 6 Hasil Pendugaan Model Pengaruh Gabungan

\begin{tabular}{|c|c|c|}
\hline Variabel & Koefisien & Nilai-p \\
\hline $\mathrm{X} 1$ & 0,647 & $<0,000$ \\
\hline $\mathrm{X} 2$ & 0,34 & 0,03 \\
\hline X3 & $-0,024$ & 0,04 \\
\hline X4 & 0,001 & 0,92 \\
\hline X5 & 0,013 & 0,76 \\
\hline X6 & 0,084 & 0,06 \\
\hline X7 & $-0,041$ & 0,41 \\
\hline X8 & $-0,034$ & 0,29 \\
\hline X9 & $-0,036$ & 0,27 \\
\hline $\mathrm{X} 10$ & $-0,003$ & 0,79 \\
\hline \multicolumn{2}{|c|}{$R^{2}$} & 0,73258 \\
\hline
\end{tabular}

Tabel 7 Hasil Pendugaan Model Pengaruh Tetap Tanpa Melibatkan X5, X7, X8, dan X9

\begin{tabular}{|c|c|c|}
\hline Variabel & Koefisien & Nilai-p \\
\hline $\mathrm{X} 1$ & 0,6 & $<0,000$ \\
\hline $\mathrm{X} 2$ & 0,416 & 0,01 \\
\hline $\mathrm{X} 3$ & $-0,021$ & 0,02 \\
\hline $\mathrm{X} 4$ & 0,007 & 0,02 \\
\hline X6 & 0,084 & 0,03 \\
\hline $\mathrm{X} 10$ & $-0,003$ & 0,03 \\
\hline \multicolumn{2}{|c|}{$R^{2}$} & 0,74953 \\
\hline
\end{tabular}

Tabel 8 Hasil Pendugaan Model Pengaruh Acak Melibatkan X1

\begin{tabular}{|c|c|c|}
\hline Variabel & Koefisien & Nilai-p \\
\hline $\mathrm{X} 1$ & 0,531 & $<0,000$ \\
\hline $\mathrm{X} 2$ & 0,469 & 0,04 \\
\hline \multicolumn{2}{|c|}{$R^{2}$} & 0,53861 \\
\hline
\end{tabular}

Tabel 9 Hasil Pendugaan Model Pengaruh Gabungan Melibatkan X1, X2, dan X3

\begin{tabular}{ccc}
\hline Variabel & Koefisien & Nilai-p \\
\hline X1 & 0,629 & $<0,000$ \\
X2 & 0,332 & 0,02 \\
X3 & $-0,022$ & 0,03 \\
\hline & & 0,716 \\
\hline
\end{tabular}

Berdasarkan Tabel 7, Tabel 8, dan Tabel 9, penelitian ini memilih Model Pengaruh tetap karena menghasilkan $R^{2}$ yang paling besar. Selanjutnya dilakukan Uji Chow dan Uji Hausman untuk mendapatkan model terbaik.

Tabel 10 Hasil Uji Chow

F 2,2624




\begin{tabular}{lc} 
Db1 & 26 \\
\hline Db2 & 115 \\
\hline Nilai-p & 0,0017 \\
\hline \multicolumn{2}{c}{ Tabel 11 Hasil Uji Hausman } \\
\hline$\chi^{2}$ & $\mathbf{6 , 7 1 0 2}$ \\
\hline Db & 1 \\
\hline Nilai-p & 0,01 \\
\hline
\end{tabular}

Berdasarkan Tabel 10 dan Tabel 11, nilai $-\mathrm{p}<\alpha=5 \%$ maka model mengikuti model pengaruh tetap. Berdasarkan hasil uji yang telah dilakukan di atas, maka diperoleh model regresi data panel dengan pengaruh tetap sebagai berikut:

$y_{i t}=0,6 x_{1 i t}+0,416 x_{2 i t}-0,021 x_{3 i t}+0,007 x_{4 i t}+0,084 x_{6 i t}-0,003 x_{10 i t}+\hat{\mu}_{i}+\varepsilon_{i t}$ dengan $R^{2}=0,74953$, artinya sebesar hampir 75\% variabel-variabel bebas pada model mampu menjelaskan variasi dari variabel terikatnya.

\subsection{Analisis Spasial}

Peta persebaran persentase penduduk sakit, persentase keluhan kesehatan, rata-rata lama sakit, fasilitas BAB (sendiri), fasilitas BAB (bersama), persentase balita tidak imunisasi DPT, dan sumber air minum sumur terlindungi di kabupaten/kota Provinsi Papua pada tahun 2017 terlihat pada gambar berikut:

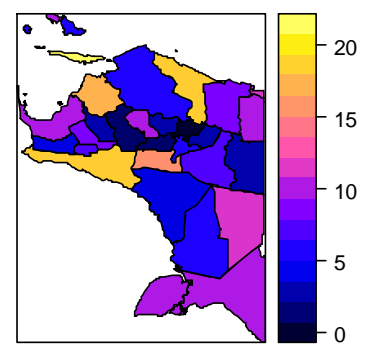

(a)

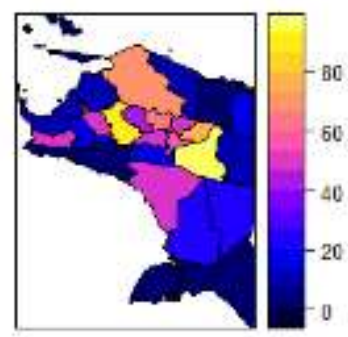

(d)

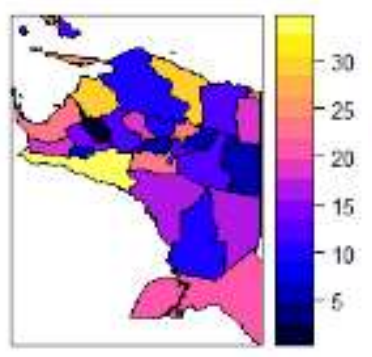

(b)

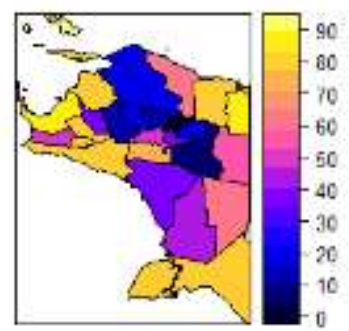

(e)

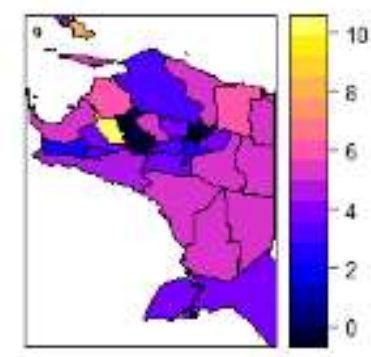

(c)

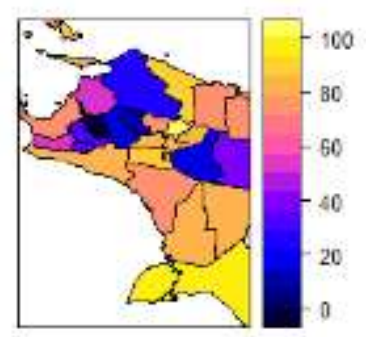

(f)

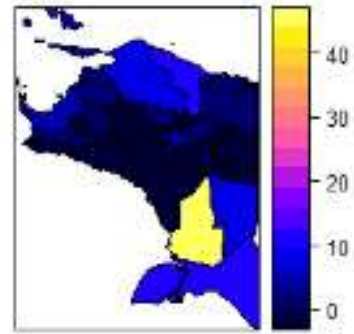




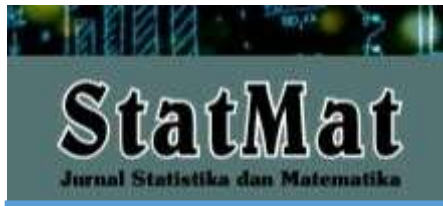

P-ISSN: 2655-3724 E-ISSN: 2720-9881

STATMAT (Jurnal Statistika dan Matematika), Vol. 2, No. 2, Juli 2020

Halaman: 176-188

@Prodi S-1 Matematika FMIPA Unpam

\section{Gambar 2 Peta Provinsi Papua tahun 2014 (a) Y (b) X1 (c) X2 (d) X3 (e) X4 (f) $\mathrm{X6}$ (g) X10}

Pada Gambar 2 terlihat bahwa secara geografis terdapat kemiripan nilai dengan tetangga kota/kab terdekatnya. Hal ini dapat dilihat pada warna peta yang menghasilkan warna yang mirip. Ini menunjukkan bahwa nilai pengamatan suatu kab/kota tidak saling bebas melainkan terdapat dependensi spasial. Pada data dengan dependensi spasial, nilai penduga yang dihasilkan dengan metode kuadrat terkecil pada regesi spasial akan menjadi bias dan tidak konsisten. Oleh karena itu, perlu dilakukan analisis data panel spasial.

Dalam melakukan analisis data spasial, terlebih dahulu dicek apakah antarkota/kab saling bebas atau tidak dengan melakukan uji otokorelasi spasial. Sebelum melakukan uji tersebut, terlebih dahulu dicari matriks pembobot spasial. Penelitian ini menggunakan konsep invers jarak untuk mendapatkan matriks pembobot spasial. Uji otokorelasi yang digunakan adalah dengan Indeks Moran Global.

Hasil uji otokorelasi spasial dapat dilihat pada Tabel 12. Berdasarkan Tabel 12 terlihat bahwa setiap variabel, antar kota saling dependen (tidak saling bebas). Oleh karena ini, selanjutnya dilakukan analisis panel spasial.

Tabel 12 Hasil uji otokorelasi spasial

\begin{tabular}{lccl}
\hline & $\boldsymbol{Z}(\boldsymbol{I})$ & $\boldsymbol{p}$-value & Keterangan \\
\hline $\mathrm{Y}$ & 2,0653 & 0,0418 & $H_{1}: I>0$; Terdapat otokorelasi spasial positif \\
$\mathrm{X} 1$ & 2,7863 & 0,008 & $H_{1}: I>0$; Terdapat otokorelasi spasial positif \\
$\mathrm{X} 2$ & 4,3524 & 0,0331 & $H_{1}: I>0$; Terdapat otokorelasi spasial positif \\
$\mathrm{X} 3$ & 2,8422 & 0,0022 & $H_{1}: I>0$; Terdapat otokorelasi spasial positif \\
X4 & 4,1936 & $<0,000$ & $H_{1}: I>0$; Terdapat otokorelasi spasial positif \\
X6 & 3,2374 & 0,000 & $H_{1}: I>0$; Terdapat otokorelasi spasial positif \\
X10 & 1,2987 & 0,009 & $H_{1}: I>0$; Terdapat otokorelasi spasial positif \\
\hline
\end{tabular}

\subsection{Analisis Panel Spasial}

Hasil pendugaan parameter dengan model panel GSM, SAR, dan SEM dapat dilihat pada Tabel 13, Tabel 14, dan Tabel 15.

Tabel 13 Pendugaan parameter model panel GSM dengan pengaruh tetap

\begin{tabular}{lcc}
\hline \multicolumn{1}{c}{ Variabel } & Koefisien & $\boldsymbol{p}-$ value \\
\hline Rho & 0,151 & 0,0318 \\
Lambda & $-0,6693$ & 0,0189 \\
X1* & 0,54 & $<0,000$ \\
X2* & 0,4372 & 0,041 \\
X3 & 0,0062 & 0,569 \\
X4* & 0,0114 & 0,026 \\
X5* & $-0,0783$ & 0,033 \\
X6 & 0,0502 & 0,158 \\
X7* & 0,0684 & 0,048 \\
X8 & $-0,0138$ & 0,615 \\
X9* & $-0,0589$ & 0,039
\end{tabular}




P-ISSN: 2655-3724 E-ISSN: 2720-9881
STATMAT (Jurnal Statistika dan Matematika), Vol. 2, No. 2, Juli 2020
Halaman: 176-188
@Prodi S-1 Matematika FMIPA Unpam

Tabel 14 Pendugaan parameter model panel SEM dengan pengaruh tetap

\begin{tabular}{lcc}
\hline \multicolumn{1}{c}{ Variabel } & Koefisien & $\boldsymbol{p}-$ value \\
\hline Lambda & $-0,4456$ & 0,017 \\
X1 & 0,541 & $<0,000$ \\
X2* & 0,398 & 0,046 \\
X3 & 0,011 & 0,288 \\
X4 & 0,011 & 0,329 \\
X5 & $-0,08$ & 0,031 \\
X6* & 0,061 & 0,028 \\
X7* & 0,062 & 0,017 \\
X8 & $-0,009$ & 0,734 \\
X9 & $-0,064$ & 0,223 \\
X10 & 0,009 & 0,368 \\
\hline \multicolumn{1}{c}{$\boldsymbol{R}^{2}$} & & 0,8303 \\
\hline
\end{tabular}

Tabel 15 Pendugaan parameter model panel SAR dengan pengaruh tetap

\begin{tabular}{|c|c|c|}
\hline Variabel & Koefisien & $p-$ value \\
\hline Rho & 0,0138 & 0,049 \\
\hline $\mathrm{X} 1 *$ & 0,5344 & $<0,000$ \\
\hline $\mathrm{X} 2 *$ & 0,42 & 0,047 \\
\hline X3 & 0,006 & 0,626 \\
\hline $\mathrm{X} 4$ & 0,007 & 0,55 \\
\hline $\mathrm{X} 5^{*}$ & $-0,065$ & 0,027 \\
\hline $\mathrm{X} 6^{*}$ & 0,074 & 0,048 \\
\hline X7 & 0,041 & 0,327 \\
\hline $\mathrm{X} 8$ & $-0,012$ & 0,686 \\
\hline $\mathrm{X} 9 *$ & $-0,064$ & 0,026 \\
\hline $\mathrm{X} 10$ & 0,008 & 0,528 \\
\hline
\end{tabular}

Dari hasil di atas, terlihat bahwa untuk setiap model, tidak semua variabel signifikan pada taraf nyata 5\%. Hasil dugaan parameter dengan hanya menyertakan variabel-variabel yang signifikan dapat dilihat pada Tabel 16, Tabel 17, dan Tabel 18.

Tabel 16 Pendugaan parameter model panel GSM pengaruh tetap dengan variabelvariabel yang signifikan

\begin{tabular}{lcc}
\hline \multicolumn{1}{c}{ Variabel } & Koefisien & $\boldsymbol{p}$-value \\
\hline Rho & 0,253 & 0,033 \\
Lambda & $-0,898$ & 0,031 \\
X1 & 0,542 & $<0,000$ \\
X2 & 0,409 & 0,04 \\
X4 & 0,013 & 0,02 \\
X5 & $-0,055$ & 0,03 \\
X7 & 0,083 & 0,018
\end{tabular}




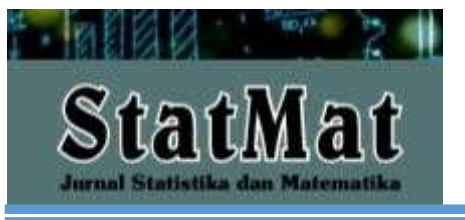

\begin{tabular}{llll} 
X9 & $-0,055$ & 0,02 \\
\hline & $\boldsymbol{R}^{\mathbf{2}}$ & & 0,8242 \\
\hline
\end{tabular}

Tabel 17 Pendugaan parameter model panel SEM pengaruh tetap dengan variabelvariabel yang signifikan

\begin{tabular}{|c|c|c|}
\hline Variabel & Koefisien & $p$-value \\
\hline Lambda & $-0,144$ & 0,028 \\
\hline $\mathrm{X} 1 *$ & 0,55 & $<0,000$ \\
\hline $\mathrm{X} 2 *$ & 0,425 & 0,039 \\
\hline $\mathrm{X} 5 *$ & $-0,046$ & 0,021 \\
\hline $\mathrm{X} 6^{*}$ & 0,044 & 0,021 \\
\hline $\mathrm{X} 7 *$ & 0,01 & 0,017 \\
\hline$R^{2}$ & & \\
\hline
\end{tabular}

Tabel 18 Pendugaan parameter model panel SAR pengaruh tetap dengan variabelvariabel yang signifikan

\begin{tabular}{|c|c|c|}
\hline Variabel & Koefisien & $p$-value \\
\hline Rho & 0,066 & 0,046 \\
\hline $\mathrm{X} 1 *$ & 0,542 & $<0,000$ \\
\hline $\mathrm{X} 2 *$ & 0,405 & 0,048 \\
\hline $\mathrm{X} 5^{*}$ & $-0,047$ & 0,013 \\
\hline $\mathrm{X} 6^{*}$ & 0,085 & 0,017 \\
\hline$\times 9 *$ & $-0,061$ & 0,007 \\
\hline$R^{2}$ & & \\
\hline
\end{tabular}

\subsection{Evaluasi Model}

Hasil perhitungan pada analisis data panel spasial, didapatkan bahwa model yang terbaik adalah model spasial otoregresi ( $S A R$ pengaruh tetap dengan variabel $\mathrm{X} 1, \mathrm{X} 2, \mathrm{X} 5$, X6, dan X9 yang signifikan dengan taraf nyata 5\% karena memiliki nilai $R^{2}$ terbesar. Hal ini dapat dilihat pada Tabel 19.

\section{Tabel 19 Evaluasi model}

\begin{tabular}{lc}
\hline \multicolumn{1}{c}{ Model } & $\boldsymbol{R}^{\mathbf{2}}$ \\
\hline Panel Pengaruh Tetap & 0,7495 \\
\hline Panel GSM Pengaruh Tetap & 0,8242 \\
\hline Panel SEM Pengaruh Tetap & 0,8204 \\
\hline Panel $S A R$ Pengaruh Tetap & 0,8292 \\
\hline
\end{tabular}

Persamaan model yang terbentuk dari model pengaruh tetap dengan SAR sebagai berikut:

$$
\begin{aligned}
y_{i t}=0,066 & \sum_{j=1}^{N} w_{i j} y_{i t}+0,542 x_{1 i t}+0,405 x_{2 i t}-0,047 x_{5 i t}+0,085 x_{6 i t}-0,061 x_{9 i t} \\
& +\varepsilon_{i t}
\end{aligned}
$$

\section{SIMPULAN}


Pemodelan data kesehatan di Provinsi Papua dengan melibatkan factor spasial dapat menghasilkan model yang lebih baik dibandingan dengan model panel biasa. Model panel $S A R$ dengan pengaruh tetap terbukti lebih baik dari model panel biasa, model panel SEM maupun model panel GSM dengan pengaruh tetap bila dilihat dari nilai $\mathrm{R}^{2}$. Berdasarkan hasil diatas, faktor-faktor yang mempengaruhi persentase sakit di provinsi Papua adalah persentase keluhan kesehatan, rata-rata lama sakit, persentase balita tidak imunisasi BCG, DPT, dan HEPATITIS B.

\section{DAFTAR PUSTAKA}

Anggraeni, Y. 2012. Analisis Spasial Data Panel untuk Menentukan Faktor-Faktor yang Mempengaruhi Kemiskinan di Provinsi Sumatera Selatan. Skripsi, Institut Pertanian Bogor, Bogor.

Anselin, L. 2009. Spatial Regression. London: Sage Publications.

Badan Pusat Statistik. 2018. Angka Kematian Balita per 1000 Kelahiran Hidup Menurut Provinsi. Dipetik Januari 5, 2020, dari https://www.bps.go.id/dynamictable/2018/06/06/1457/angka-kematian-balita-per1000-kelahiran-hidup-menurut-provinsi-2012-dan-2017.html

Badan Pusat Statistik. 2019. Persentase Rumah Tangga Kumuh Perkotaan Menurut Provinsi. Dipetik Januari 05, 2020, dari https://www.bps.go.id/dynamictable/2019/10/04/1667/persentase-rumah-tanggakumuh-perkotaan-40-ke-bawah-menurut-provinsi-2015-2018.html

Badan Pusat Statistik. 2019. Persentase Rumah Tangga yang Memiliki Akses terhadap Layanan Sanitasi Layak dan Berkelanjutan Menurut Provinsi. Dipetik Januari 5, 2020, dari https://www.bps.go.id/dynamictable/2019/10/04/1665/persentase-rumahtangga-yang-memiliki-akses-terhadap-layanan-sanitasi-layak-dan-berkelanjutan-40bawah-menurut-provinsi-2015-2018.html

Badan Pusat Statistik. 2019. Persentase Rumah Tangga yang memiliki Akses terhadap Layanan Sumber Air Minum Layak dan Berkelanjutan Menurut Provinsi. Dipetik Januari 5, 2020, dari https://www.bps.go.id/dynamictable/2019/10/04/1663/persentase-rumah-tanggayang-memiliki-akses-terhadap-layanan-sumber-air-minum-layak-danberkelanjutan-40-bawah-menurut-provinsi-2015-2018.html

Baltagi, B. 2005. Econometrics Analysis of Panel Data (3rd ed.). England: John Wiley \& Sons.

CNN Indonesia. 2018. Catatan Kesehatan Indonesia Sepanjang 2018. Dipetik Januari 5, 2020, dari https://www.cnnindonesia.com/gaya-hidup/20181217130400-255354250/catatan-kesehatan-indonesia-sepanjang-2018

Elhorst, J. 2010. Spatial Panel Data Models. New York: Springer.

Halim, S. 2008. Penentuan Harga Jual Hunian pada Apartemen di Surabaya dengan Menggunakan Metode Regresi Spasial. Jurnal Teknik Industri, 10(2): 151-157.

Kementerian Kesehatan Republik Indonesia. 2018. Hasil Riskesdas 2018. Dipetik Januari 5, 2020 , http://www.kesmas.kemkes.go.id/assets/upload/dir_519d41d8cd98f00/files/Hasilriskesdas-2018_1274.pdf

Kementerian Kesehatan Republik Indonesia. 2019. Program Indonesia Sehat untuk Capai Tingkat Kesehatan Tertinggi. Dipetik Januari 5, 2020, dari http://sehatnegeriku.kemkes.go.id/baca/rilis-media/20190521/5530314/program- 
indonesia-sehat-capai-tingkat-kesehatan-tertinggi/

Kumparan. 2019. 10 Years Challenge: Melihat Kondisi Kesehatan Masyarakat Indonesia. Dipetik Januari 5, 2020, dari https://kumparan.com/kumparansains/10-yearschallenge-melihat-kondisi-kesehatan-masyarakat-indonesia$1547773566224815409 /$ full

Meilliana, A. 2013. Analisis Statistika Faktor yang Mempengarugi Indeks Pembangunan Manusia di Kabupaten/Kota Provinsi Jawa Timur dengan Menggunakan Regresi panel. Jurnal Sains dan Seni, 2(2): 237-242.

Pangestika, S. 2015. Analisis Estimasi Model Regresi Data Panel dengan Pendekatan Common Effect Model (CEM), Fixed Effect Model (FEM), dan Random Effect Model (REM). Skripsi, Universitas Negeri Semarang, Semarang.

Rahayu, T. E. 2010. Pertumbuhan dan Persebaran Penduduk Indonesia (Hasil Sensus Penduduk 2010). Dipetik Januari 5, 2020, dari https://media.neliti.com/media/publications/49963-ID-pertumbuhan-danpersebaranpenduduk-indonesia.pdf 